\title{
8: $82355340-82359563$
}

National Cancer Institute

\section{Source}

National Cancer Institute. 8: 82355340-82359563. NCI Thesaurus. Code C42243.

Physical location of FABP5_Gene 